\title{
The Disinfection of Drinking Water in Trunk Water Mains
}

\author{
Rodney McDermott, Sandra Orr, Steven Sproule \\ Belfast School of Architecture and the Built Environment, Ulster University, Newtownabbey, UK \\ Email: r.mcdermott@ulster.ac.uk
}

How to cite this paper: McDermott, R. Orr, S. and Sproule, S. (2019) The Disinfection of Drinking Water in Trunk Water Mains. Journal of Environmental Protection, 10, 1085-1104. https://doi.org/10.4236/jep.2019.109064

Received: May 14, 2019

Accepted: September 2, 2019

Published: September 5, 2019

Copyright (c) 2019 by author(s) and Scientific Research Publishing Inc. This work is licensed under the Creative Commons Attribution International License (CC BY 4.0).

http://creativecommons.org/licenses/by/4.0/

(c) (i) Open Access

\begin{abstract}
This study aimed to explore the disinfection of drinking water in trunk water mains, based on published conditions denoted within the Irish Republic. The variables within the study were consumer draw-off rates, trunk main length, pipe diameter, and water temperature. All these factors are known to impact the free chlorine residual in operational supply networks. Based on published conditions obtained within the literature review, 60 hypothetical trunk mains were generated for this study. Of primary concern were the variables that affect the chlorine decay rate; total amount of chlorine decay; available amount of chlorine in the periphery of the trunk main; and the costs associated with effective chlorine disinfection of trunk mains. Based on the analysis performed, the following were the salient observations: 1) Low consumer draw-off rates and increased trunk main length and diameter increased the risk of the free chlorine residual in the periphery of the trunk mains not complying with the Environmental Protection Agency's (EPA) minimum recommended residual value of $0.1 \mathrm{mg} / \mathrm{l}$ (EPA Drinking Water Audit Report, 2014). 2) Increasing the diameter of the trunk main from 125 $\mathrm{mm}$ to $180 \mathrm{~mm}$ had a negligible effect on the chlorine decay rate. However, increasing the trunk main diameter from $125 \mathrm{~mm}$ to $180 \mathrm{~mm}$ was shown to have a major impact on the total amount of chlorine decay and free chlorine residual available in the periphery of the main. The key parameters that affected disinfection costs associated with trunk mains include length, diameter and the need for chlorine boosting.
\end{abstract}

\section{Keywords}

Disinfection of Water, Chlorine, Trunk Mains, Operational Expenditure

\section{Introduction}

In Ireland, potable water is generally treated using the conventional treatment 
processes of coagulation, sedimentation, filtration and disinfection by chlorine at a Water Treatment Plant (WTP) (LeChevallier \& Au, 2004) [1]. In industry, it is widely agreed that the disinfection process is the most important stage of water treatment because it neutralises harmful organisms and helps guarantee the safety of palatable drinking water (Abdullah, et al., 2003 [2]; Boccelli, et al., 2003 [3]; LeChevallier \& Au, 2004 [1]; Sohn, et al., 2004) [4]).

Although the quality of drinking water is measured through tests associated with physical, chemical and biological parameters (Purcell, 2003) [5], there have been published cases where the quality of potable water has not met the required regulatory requirements. This includes the European Union (EU) Drinking Water Directive 98/83/EC, 1998 [6]. The cause of these failings was attributed to either sub-optimal treatment at a WTP or other factors within the distribution network (EPA \& HSE, 2011) [7]. Despite extensive published information on the disinfection of drinking water and numerous mathematical hypothesis created to model and predict the chlorine residual in a trunk main as part of a distribution network. There is limited research material published on the factors that affect the installation and operation of chlorine management within the network or the costs associated with chlorine disinfection at the WTPs. Therefore, despite the need for suitable models that help WTP operators in Ireland to assess the parameters which affect the free chlorine residual in the distribution network, limited progress has been made towards achieving this goal. This demonstrates a gap in knowledge regarding the disinfection of drinking water in distribution networks. Therefore, the aim of this study was to propose a practical mathematical model to predict chlorine concentration within a trunk main.

\section{Literature Review}

Chlorine has been the disinfectant of choice for over 100 years (Hass \& Kara, 1984) [8]. It is still the most widely used form of disinfection of drinking water in Europe (Eureau, 2014) [9] and the United States of America (USA) (Silva et al. 2010) [10]. The disinfectant is typically applied at the final stage of the water treatment process (Kohpaei \& Sathasivan, 2011) [11]. Chlorine-based products are the only disinfectants that can produce a lasting and effective residual in the distribution network. The residual protects the treated water from recontamination in the distribution network - from the WTP to the consumers tap (Spellman, 2004) [12]. To ensure the safe distribution of drinking water, water companies set a minimum residual level for the entire network as part of their safe management plan. The EPA (2011) [13] currently specifies a free chlorine residual of $0.1 \mathrm{mg} / \mathrm{l}$ to be present in the periphery of the distribution network.

A maximum health-based free or combined chlorine residual guideline value of $5 \mathrm{mg} / \mathrm{l}$ has been set by the World Health Organisation (WHO) for drinking water (WHO, 1996) [14]. However, the residual levels in the UK are well below this guideline with most water companies aiming to keep the level below $1 \mathrm{mg} / \mathrm{l}$ (DWI, 2010) [15]. Accordingly, consumers located closer to the WTP/reservoir 
will normally obtain tap water with higher chlorine levels compared to consumers several miles away, as suggested by Chick's Law of Disinfection [5]. Consequently, water companies must have a residual disinfectant management policy in place to guarantee the inhibition of bacterial regrowth in the periphery of the distribution network whilst ensuring the maximum level is acceptable to consumers (DWI, 2010) [15]. In large distribution networks, chlorine concentrations may drop below the minimum desired level at the periphery of the network as denoted by observed chlorine decay rates. Where the chlorine residual decays to an unacceptable level, current practice is to install a chlorine booster to ensure the free chlorine residual remains above the minimum residual or threshold level (Lu et al., 1999) [16].

Chlorine decay in the distribution network is due to either bulk decay (reaction with microbes or organics) and/or pipe wall decay (reaction with biofilm, corrosion and sediments) (Speight, 2008) [17]. The decay of a chlorine residual can pose a major threat to the microbial safety of drinking water by weakening its protective barriers and increasing the risk of recontamination in the distribution network (Egbe \& Bassey, 2016) [18]. There are no universally accepted mathematical equations to calculate the variational chlorine decay rate in a distribution network. However, the equation proposed by Nagatani et al. (2006) [19], Equation (1), has been shown to closely match other published experimental observations.

$$
\frac{\mathrm{d} C}{\mathrm{~d} t}=k_{b} \cdot C+\frac{4}{d} \cdot k_{w}
$$

where:

$\mathrm{d} C$ Change in chlorine concentration

$\mathrm{d} t \quad$ Change in residence time

C Free chlorine concentration (mg/l)

$k_{b} \quad$ Bulk decay coefficient (/hour)

$k_{w} \quad$ Pipe wall decay coefficient (/hour)

$d \quad$ Pipe diameter ( $\mathrm{mm}$ )

Laboratory experiments conducted by Al-Omari et al. (2004) [20] indicated the important predictors of bulk chlorine decay include initial chlorine concentration, temperature and Total Organic Carbon (TOC) in the water. The rate of bulk chlorine decay has been recorded by several researchers to increase as the free chlorine concentration, temperature and TOC levels increased (Feban \& Taras 1951 [21]; Jadas-Hecar, et al. 1992 [22]; Zhang, et al. 1992 [23]; Powell, et al. 1999 [24]; Al-Omari [20], et al. 2004; Nagatani et al. 2006) [19]. There are a considerable number of mathematical equations used to calculate the bulk chlorine decay coefficient. However, the first-order equation proposed by Al-Omari et al. (2004) (Equation (2)) [20], is a recognised best fit to published datasets.

$$
k_{b}=41,233 \cdot C_{o}^{-0.76} \cdot \mathrm{e}^{1.388 \cdot T O C} \cdot \mathrm{e}^{\frac{-4590.5}{T}}
$$

where: 
$K_{b} \quad$ Bulk decay coefficient (/hour)

$C_{o} \quad$ Initial chlorine concentration (mg/l)

$e \quad$ Euler's number

TOC Total Organic Carbon (mg/l)

$T \quad$ Temperature (Kelvin)

Research conducted by Hallam et al. (2002) [25] determined the effects of pipe condition and material on the pipe wall decay coefficient $\left(k_{w}\right)$. The results of the research are shown in Table 1.

Due to many variables required to determine the rate of chlorine decay, Al-Omari et al. (2004) [20] believe the accuracy of mathematical chlorine decay models is highly dependent on the accuracy of the input data provided. Thus, each distribution network must be assessed individually, according to its specific environmental conditions (Powell et al., 1999) [24].

\section{Method}

\section{Input Variables}

This study sought to produce data obtained via scenario testing. Scenario testing is a structured method of conducting research which can produce amounts of credible data for complex hypothetical or real-life scenarios comparison (Cem-Kaner, 2013) [26]. Hypothetical scenario testing utilises both variable and constant parameters. For this research study, the parameters were derived from the literature review, based on published conditions. These parameters allowed development of 60 hypothetical scenarios that were assessed as part of the data analysis of this study, 30 No. $125 \mathrm{~mm}$ trunk mains referenced 1 - 30, and 30 No. 180 mm trunk mains referenced 31 - 60 (Table 2). The use of "main" or "mains" herein refers to "trunk mains" as part of an overall water distribution network.

The variables assessed for this study included:

- Population (number of consumers);

- Trunk main length;

- Trunk main diameter;

- Water temperature.

The constant parameters for this study included:

- The average water consumption per person per day in Ireland (150 litres) judged to be drawn off over a 16-hour period;

Table 1. Effect of wall material on wall chlorine decay constant (Hallam et al., 2002) [25].

\begin{tabular}{cc}
\hline Pipe Material & Pipe Wall Decay Coefficient $\left(\boldsymbol{k}_{w}\right)$ \\
\hline Cast iron & 0.67 \\
Spun iron & 0.33 \\
Cement-lined ductile iron & 0.13 \\
Medium density polyethylene & 0.05 \\
Polyvinyl chloride & 0.09
\end{tabular}


Table 2. Summary of the parameters assessed for the 60 trunk mains.

\begin{tabular}{cc}
\hline Description & Parameter \\
\hline Population (number of consumers) & $200 ; 500$ and 1000 \\
Water consumption per person (litres/16hr) & 150 \\
Chlorine residual $(\mathrm{mg} / \mathrm{l})$ & 1.0 \\
Pipe wall decay coefficient $\left(k_{w} / \mathrm{hr}\right)$ & 0.05 \\
Total organic carbon in water $(\mathrm{mg} / \mathrm{l})$ & 1.8 \\
Main type & SDR11 MDPE \\
Water temperature $\left({ }^{\circ} \mathrm{C}\right)$ & 5 \& 15 \\
Main length $(\mathrm{m})$ & 2000; 4000; 6000, 8000 and 10,000 \\
Main diameter $(\mathrm{mm})$ & 125 \\
\end{tabular}

- The initial free chlorine residual (1.0 mg/l);

- Trunk main type (SDR11 MDPE);

- The zero-order pipe wall decay constant $(0.05 / \mathrm{hr})$;

- TOC levels in water $(1.8 \mathrm{mg} / \mathrm{l})$.

Table 2 provides a summary of the parameters assessed for each trunk main.

A spreadsheet was produced to enable the data obtained from scenario testing to be collected in a structured manner. This structured systematic approach enabled the data to be analysed and compared. Implementing the variables and constants outlined above, into multiple scenarios enabled the rate of chlorine decay and the available free chlorine residual in the periphery of the trunk main to be calculated. The following parameters remained as a constant for each trunk main installation:

- A single, straight trunk main was installed without bends;

- The trunk main connected directly to the distribution main which is at the end of the trunk main.

The following parameters remained as constants, to calculate the cost of the chlorine disinfection and maintenance of a free chlorine residual:

- The chlorine demand of the water, during primary disinfection at the WTP was $1.89 \mathrm{mg} / \mathrm{l}$ (Casey et al., 2012) [27];

- A chlorine residual of $1.0 \mathrm{mg} / \mathrm{l}$ leaving the WTP was required, in accordance with the Drinking Water Inspectorate's (DWI) guidance (DWI, 2010) [15].

\section{Results and Discussion}

\subsection{Population}

Three population ranges were chosen, within the analysis, to assess how water consumption rates and the retention time of potable water in a trunk main would affect the quality and quantity of the free chlorine residual at the extremity of the main. The population ranged between 200 consumers (a small Irish village), 500 consumers (a medium sized Irish village) and 1000 consumers (a 
relatively large Irish village) (NISRA, 2011) [28].

For each population range, two trunk mains of $125 \mathrm{~mm}$ and $180 \mathrm{~mm}$ diameter were assessed in increments of $2000 \mathrm{~m}$ starting at $2000 \mathrm{~m}$ up to $10,000 \mathrm{~m}$.

The volume of potable water contained within each trunk main was calculated (Table 3). It is interesting to note that, for a given length, increasing the diameter of the trunk main from $125 \mathrm{~mm}$ to $180 \mathrm{~mm}$ more than doubled the volume of water in the main. The average water consumption per population per hour was calculated, based on the research conducted by Ó Fátharta (2013) [29] on behalf of Irish Water. Ó Fátharta (2013) [29] determined the average person in Ireland uses 150 litres of water per day. The results are illustrated in Figure 1. Based on the volume of potable water in the trunk main (Table 3 ) and consumer draw-off rates (Figure 1), the retention time of potable water in the $125 \mathrm{~mm}$ and $180 \mathrm{~mm}$ diameter trunk mains were calculated and modelled.

Figure 2 and Figure 3 demonstrated that as the number of consumers increased, the retention time of potable water in the trunk main decreased. Additionally, increasing the trunk main diameter from $125 \mathrm{~mm}$ to $180 \mathrm{~mm}$ increased the retention time of potable water in the main by slightly over two-fold for any given test situation.

The free chlorine residual in the trunk main is impacted by interaction with bulk water and/or the pipe wall which results in the available free chlorine residual reducing over time. Therefore, increased retention time resulted in the available free chlorine residual in the periphery of the main being reduced. The

Table 3. Volume of water contained in various trunk mains of various length and diameter.

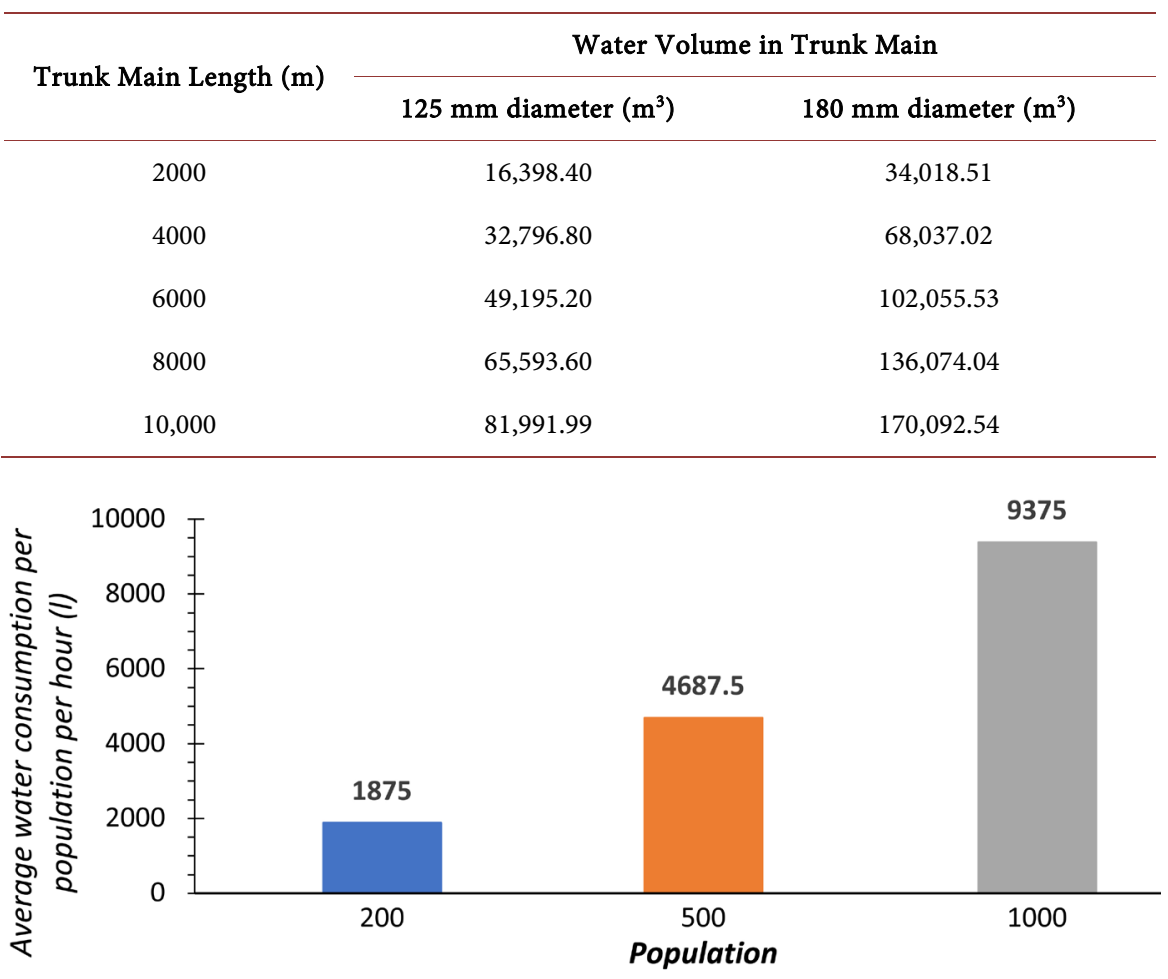

Figure 1. Average water draw-off rates per various population sizes per hour. 


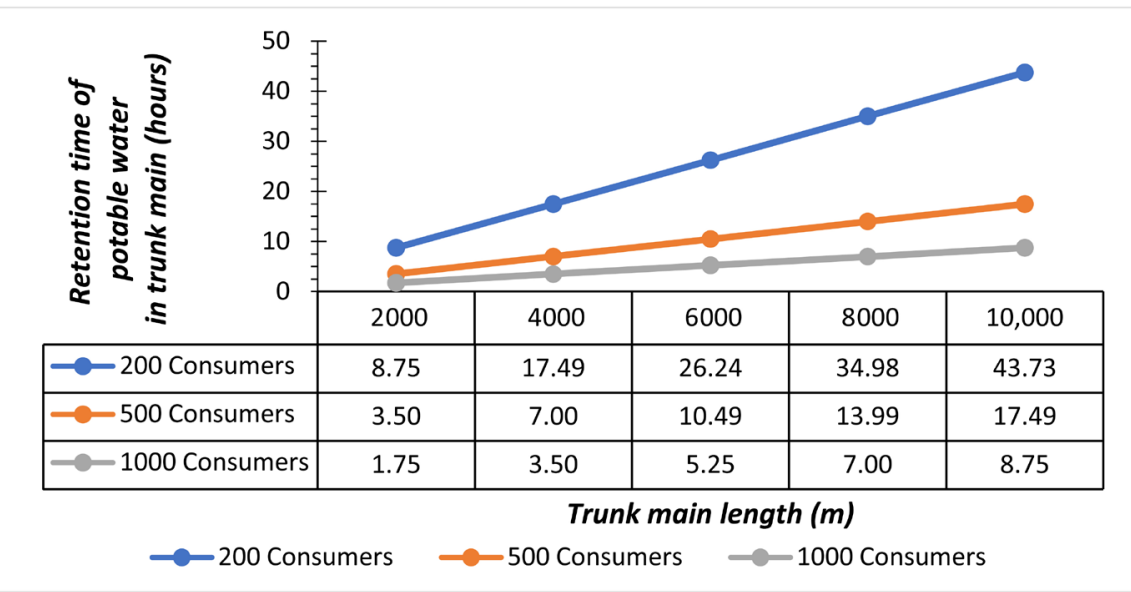

Figure 2. Retention time of water in $125 \mathrm{~mm}$ diameter trunk main for various consumer ranges.

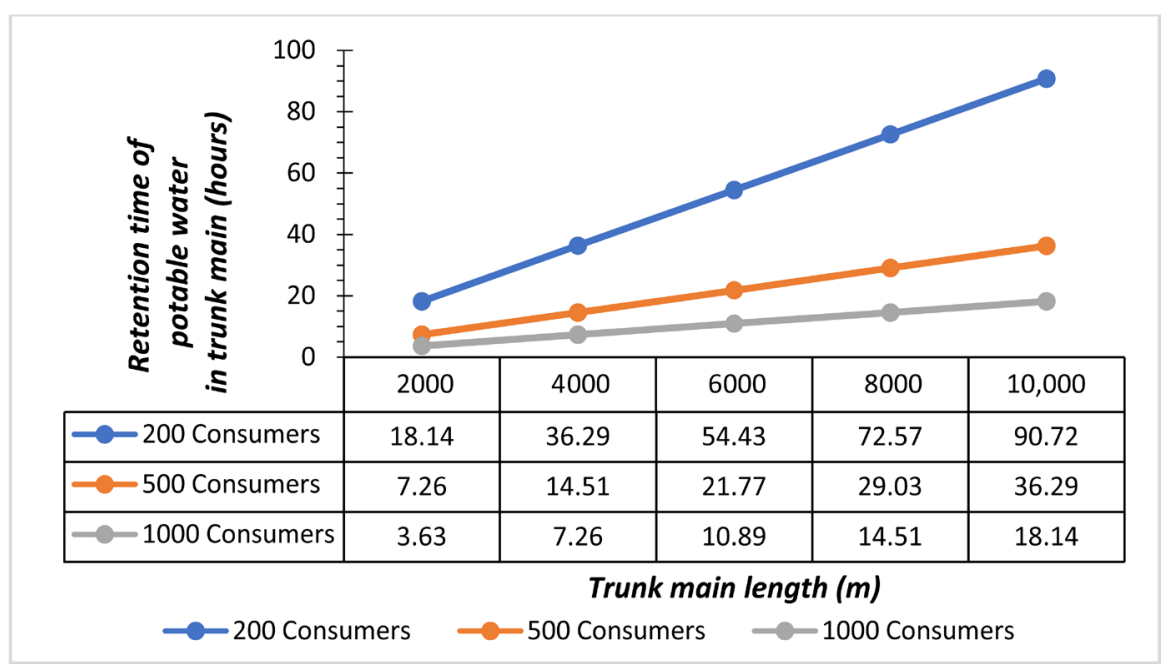

Figure 3. Retention time of water in $180 \mathrm{~mm}$ diameter trunk main for various consumer ranges.

reduction can fall within acceptable limits below the EPA's (2011) [13] recommended minimum residual values or the worst case of no chlorine residual being present. The EPA considers a retention time of potable water to be high if it exceeds 48 hours in the distribution network (EPA, 1999) [30], due to the increased risk of the free chlorine residual reducing below EPA's (2011) [13] recommended minimum residual value and the increased risk of Trihalomethanes (THM) [13] formation. As shown in Figure 2, none of the $125 \mathrm{~mm}$ diameter trunk mains had a retention time of potable water greater than 48 hours. However, this study has shown the free chlorine residual level in the $125 \mathrm{~mm}$ diameter trunk main reduced below the EPA's (2011) [13] recommended minimum free chlorine residual value at a retention time just under 17.5 hours.

Figure 3 indicates three $180 \mathrm{~mm}$ diameter trunk mains had a retention time of potable water greater than 48 hours for the hypothesis tested. Furthermore, this study showed the free chlorine residual level in the $180 \mathrm{~mm}$ trunk main re- 
duced below EPA's (2011) [13] recommended minimum free chlorine residual value of $0.1 \mathrm{mg} / \mathrm{l}$ at a retention time just under 18.15 hours.

This study demonstrated that increasing the number of consumers and decreasing the diameter of the trunk main reduced the retention time of potable water in the network. Thus, decreasing the number of consumers and increasing the diameter of the trunk main increased the retention time of the potable water in the network. Increasing the retention time of potable water in the trunk main has been shown to reduce the number of trunk main networks to be compliant with EPA's (2011) [13] minimum free chlorine residual value of $0.1 \mathrm{mg} / \mathrm{l}$, at the periphery of the trunk main (Figure 4).

\subsection{Length of Trunk Main}

The effects of trunk main length on the total amount of chlorine decay and the availability of a free chlorine residual in the outer edges of the 60-trunk mains were assessed. The total amount of chlorine decay and the availability of a free chlorine residual in the periphery of each of the mains (as shown in Table 2) were assessed in increments of $2000 \mathrm{~m}$, starting at $2 \mathrm{~km}$ up to $10 \mathrm{~km}$.

Increasing the length of the $125 \mathrm{~mm}$ and $180 \mathrm{~mm}$ diameter trunk mains in
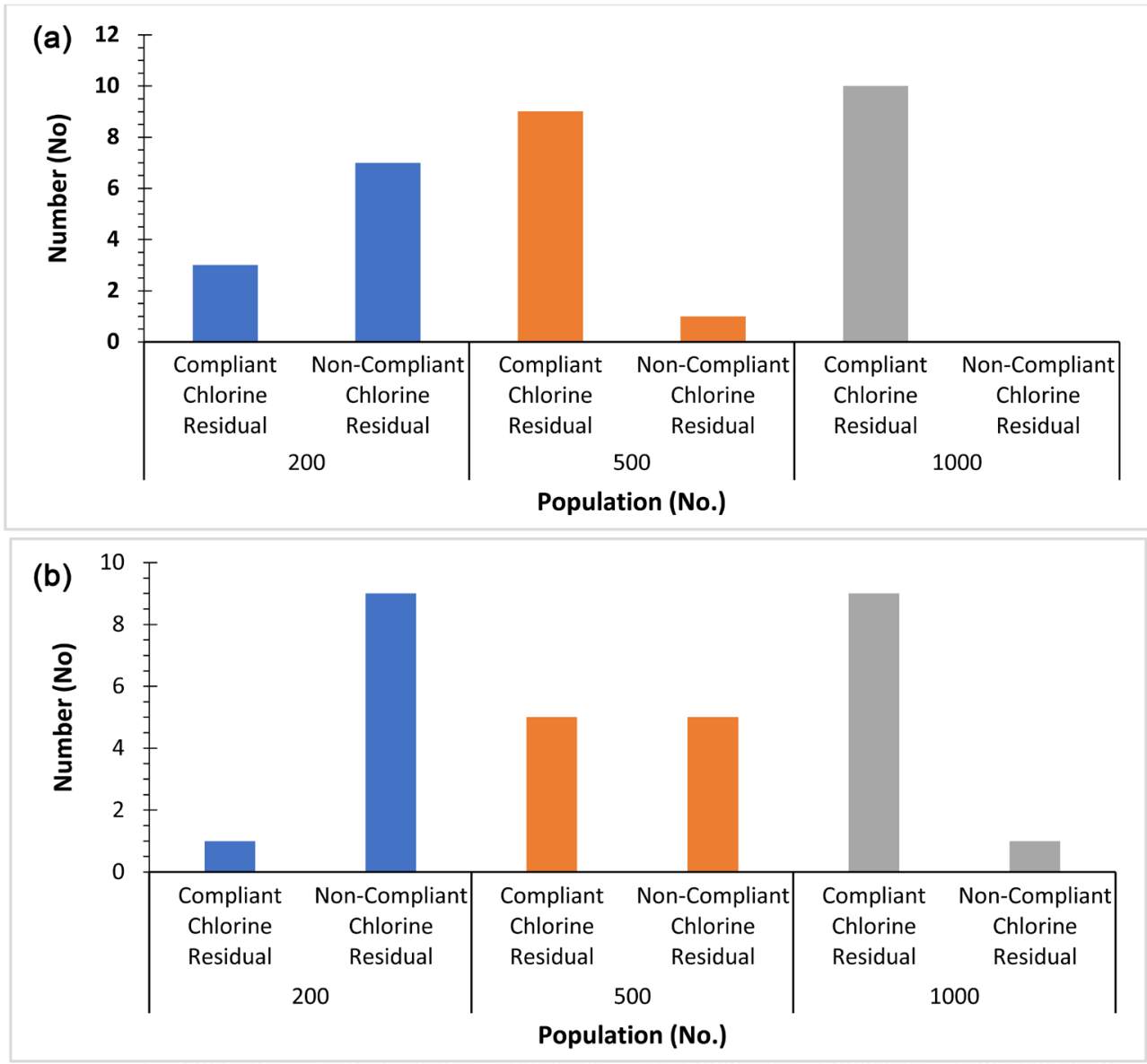

Figure 4. Number of scenarios compliant or non-compliant with EPA's minimum free chlorine residual of $0.1 \mathrm{mg} / \mathrm{l}$, in periphery of trunk main. (a) trunk mains $1-30$ and (b) trunk mains $31-60$. 
increments of 2,000 $\mathrm{m}$ increased the volume of potable water in the respective mains (Table 3).

Increasing the length of the trunk main, regardless of its diameter and draw-off rates, increased the retention time of the potable water in each main (Figure 2 and Figure 3). The free chlorine residual reacts with the bulk water and/or the pipe wall. Thus, increased retention time resulted in an increased total amount of chlorine decay in the periphery of the mains (Figure 5 and Figure 6).

An increased total amount of chlorine decay in the periphery of the main ultimately resulted in a reduced free chlorine residual available (Figure 7 and Figure 8).

Previous research by Shamsaei, et al. (2012) [31] and Egbe \& Bassey (2016) [18] on the effects of distribution main length and retention times, concluded that the length of a distribution main was the major cause of chlorine consumption and decrease in residual chlorine concentrations. This was due to an increased volume of potable water in the main and a longer distance the potable water must travel to reach the last consumer. The results obtained in this study,

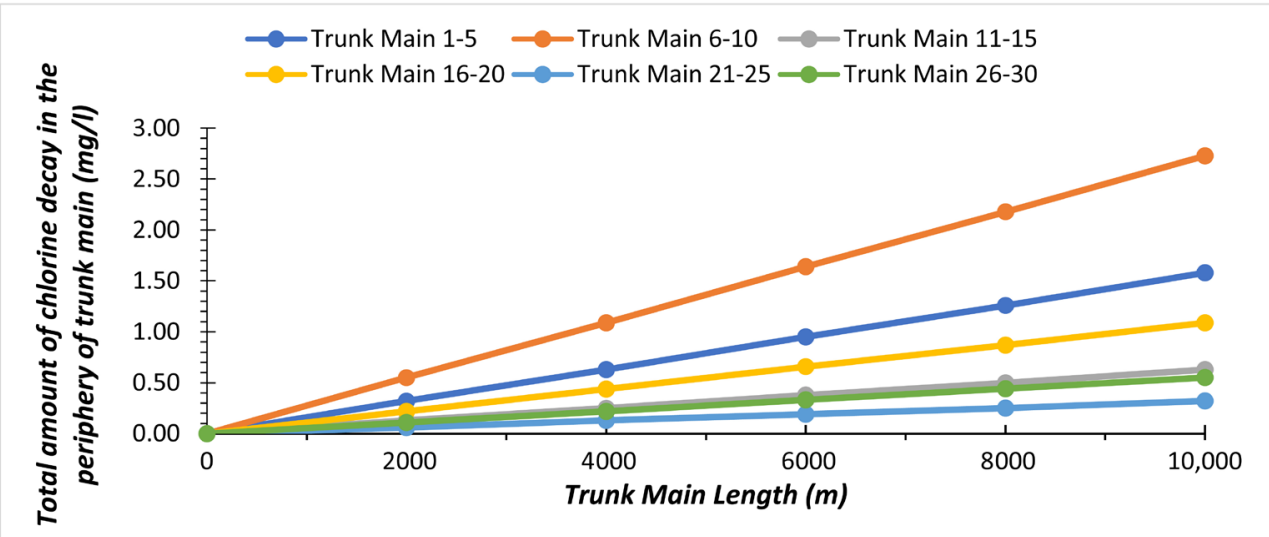

Figure 5. Total amount of chlorine decay in the periphery of trunk mains $1-30$.

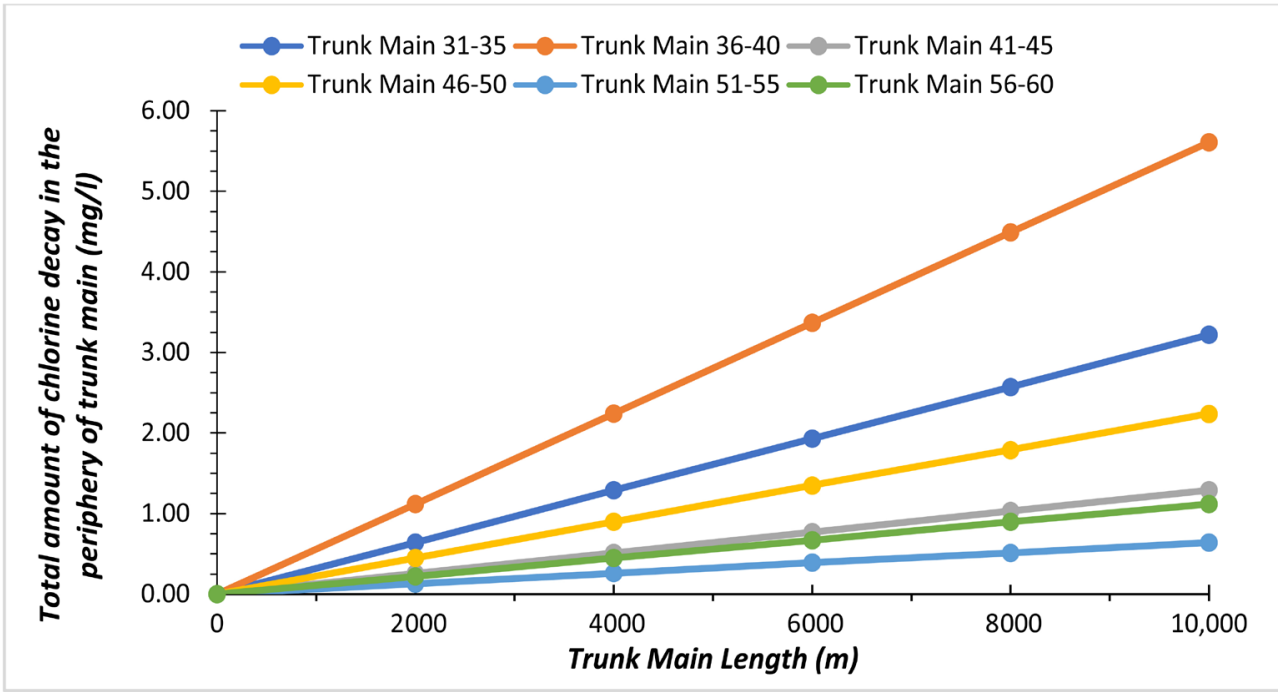

Figure 6. Total amount of chlorine decay in the periphery of trunk mains $31-60$. 


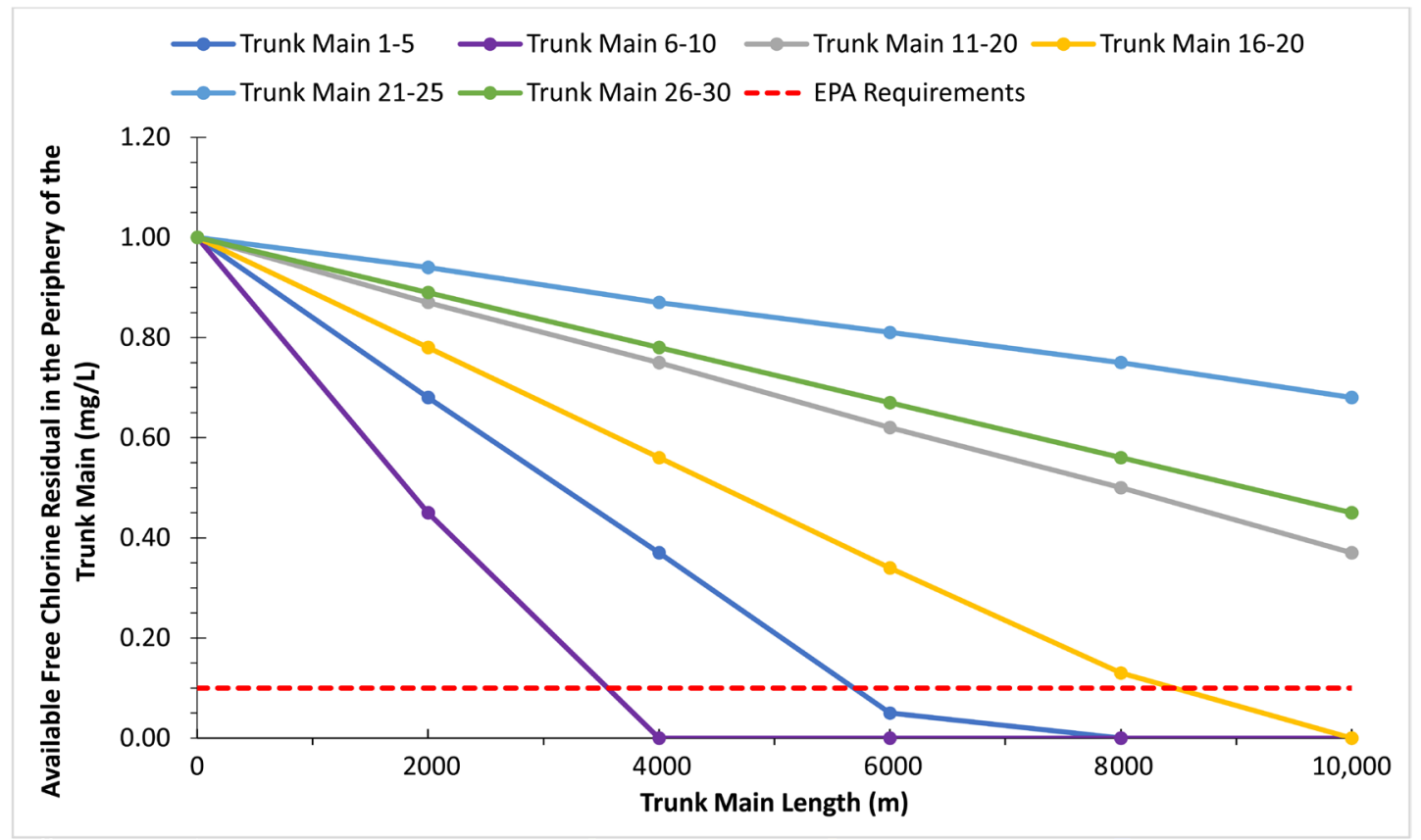

Figure 7. Available free chlorine residual in the periphery of trunk mains $1-30$.

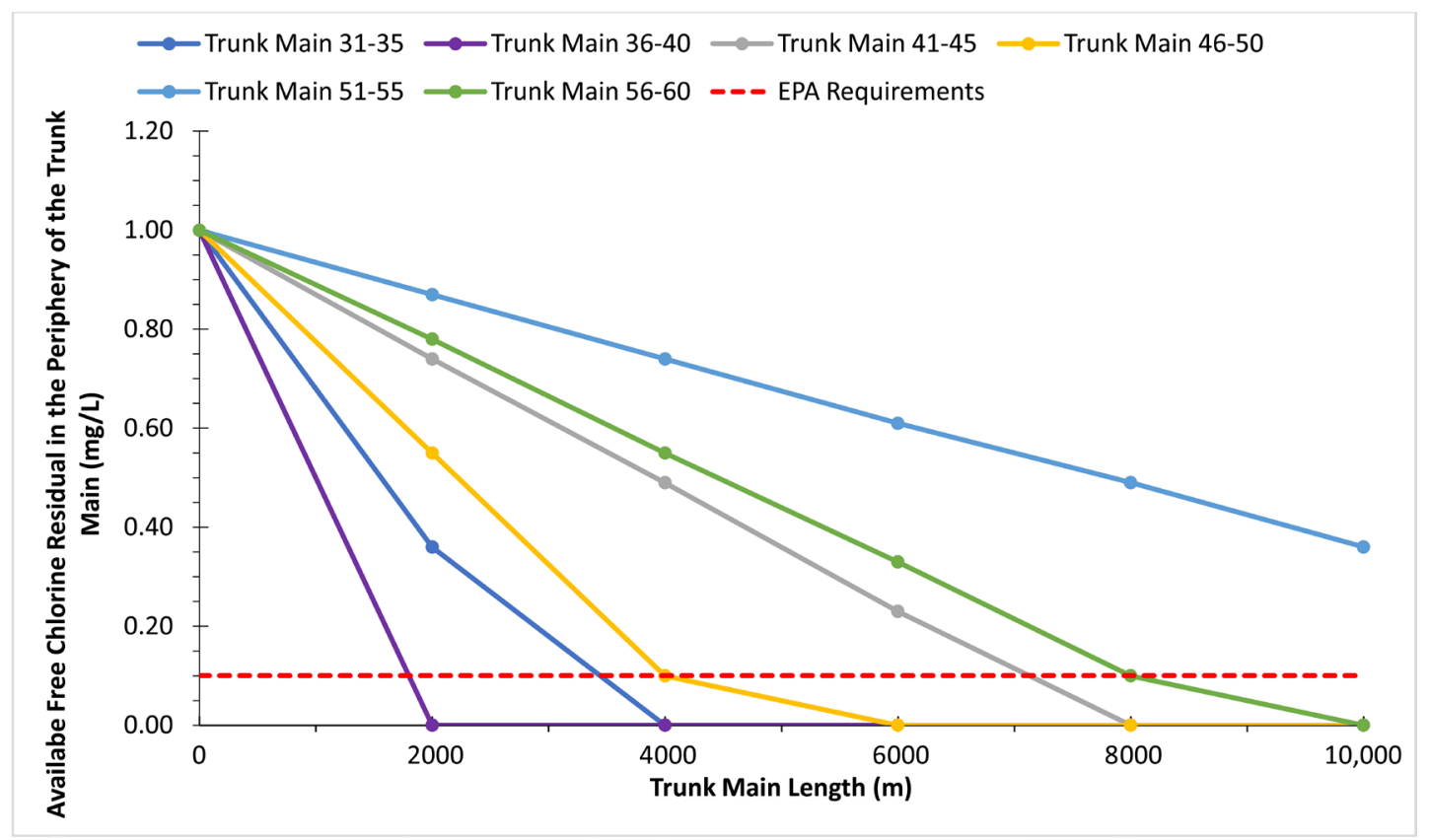

Figure 8. Available free chlorine residual in the periphery of trunk mains $31-60$.

as illustrated in Figures 5-8, are comparable with the findings by Shamsaei, et al. (2012) [31] and Egbe \& Bassey (2016) [18]. A comparison between a $2 \mathrm{~km}$ and a $10 \mathrm{~km}$ trunk main was made to assess how increasing the length of the trunk main reduced the free chlorine residual. The $2 \mathrm{~km}$ main has a free chlorine residual in the periphery of the main of $0.87 \mathrm{mg} / \mathrm{l}$. Alternatively, the $10 \mathrm{~km}$ trunk main had a free chlorine residual in the periphery of the main of $0.37 \mathrm{mg} / \mathrm{l}$. Thus, increasing the length of the trunk main from $2 \mathrm{~km}$ to $10 \mathrm{~km}$ reduced the 
available amount of free chlorine residual in the main by $0.5 \mathrm{mg} / \mathrm{l}$ for the hypothesis tested. In many cases, increasing the length of the trunk main resulted in the free chlorine residual reducing to zero (Figure 7 and Figure 8). At the point where the free chlorine residual falls below the EPA's (2011) [13] recommended minimum value of $0.1 \mathrm{mg} / \mathrm{l}$, a chlorine booster should be installed.

Trunk mains 1-10 and 31-40 had the greatest total amount of chlorine decay at the periphery of the mains assessed. As a result, these sets had the least number of trunk mains that had an available free chlorine residual value above the EPA's (2011) [13] recommended minimum value. Thus, more trunk mains within these sets required a chlorine booster. Of the trunk mains sets $1-10$ and $31-40,16$ of the 20 trunk mains required a chlorine booster. Due to extremely high total amounts of chlorine decay in the periphery of trunk mains 35 and 38, two chlorine boosters were required, trunk main 39 required three chlorine boosters and trunk main 40 required four chlorine boosters, to ensure the free chlorine residual remained above EPA's minimum residual value. By comparison, trunk mains $21-30$ and $51-60$ had the lowest total amount of chlorine decay at the fringes of the mains assessed. As a result, trunk mains 21 - 30 and 51 60 had the greatest number of mains that had an available free chlorine residual value above EPA's (2011) [13] recommended minimum residual value of 0.1 $\mathrm{mg} / \mathrm{l}$. Thus, less trunk mains within these sets required a chlorine booster. Of the trunk main sets $21-30$ and $51-60,1$ of the 20 trunk mains required a chlorine booster, main 60 which had the maximum length of trunk main assessed at 10 $\mathrm{km}$, to ensure the residual remained above the EPA's (2011) [13] recommended minimum value.

\subsection{Diameter of Trunk Main}

Two standard dimensional ratios (SDR)s 11 Medium Density Polyethylene (MDPE) trunk mains of $125 \mathrm{~mm}$ and $180 \mathrm{~mm}$ diameter were assessed within this study. To calculate the rate of chlorine decay in the trunk main, Equation (1) proposed by Nagatani et al. (2006) [19] was used. This equation takes the bulk decay coefficient, the initial free chlorine residual, trunk main diameter and the pipe wall decay coefficient into consideration. Performing the chlorine decay rate equation (Equation (1)) proposed by Nagatani et al. (2006) [19], produced the results shown in Table 4.

Based on the analysis, it was calculated that increasing the diameter of the trunk main from $125 \mathrm{~mm}$ to $180 \mathrm{~mm}$ did not alter the chlorine decay rate. This is contradictory to the results obtained from experimental studies conducted by Risala \& Kifah (2011) [32], Ekeng \& Agunwamba (2011) [33] and Egbe \& Bassey

Table 4. Chlorine decay rate in $125 \mathrm{~mm}$ and $180 \mathrm{~mm}$ diameter trunk mains.

\begin{tabular}{ccc}
\hline Pipe Diameter $(\mathrm{mm})$ & Chlorine Decay Rate $(\mathrm{mg} / \mathrm{hr})$ at $5^{\circ} \mathrm{C}$ & Chlorine Decay Rate $(\mathrm{mg} / \mathrm{hr})$ at $15^{\circ} \mathrm{C}$ \\
\hline 125 & 0.04 & 0.06 \\
180 & 0.04 & 0.06 \\
\hline
\end{tabular}


(2016) [18]. The studies conducted by these researchers found the rate of chlorine decay to increase in smaller diameter trunk mains and decrease in larger diameter trunk mains.

Based on the computations performed, it became evident that changing the diameter of the trunk main had a negligible effect on the chlorine decay rate due to the use of an MDPE trunk main due to the low Pipe Wall Decay Coefficient $\left(k_{w}\right)$. Research conducted by Hallam et al. (2002) [25] has shown the pipe wall decay coefficient of MDPE trunk mains to have a negligible effect on the total chlorine decay rate. Although increasing the diameter of the trunk main for this study had a negligible effect on the chlorine decay rate, increasing the trunk main diameter had a major impact on the total amount of chlorine decay and ultimately the amount of available free chlorine residual in the main.

Increasing the trunk main diameter from $125 \mathrm{~mm}$ to $180 \mathrm{~mm}$ increased the volume of potable water in the main by slightly more than two-fold (Table 3 ). An increased volume of potable water in the main resulted in an increased retention time of potable water (Figure 2 and Figure 3). Increased retention time allowed more time for the free chlorine residual to react with the bulk water, resulting in an increased total amount of chlorine decay in the periphery of the main (Figure 5 and Figure 6). Thus, increasing the trunk main diameter reduces the available free chlorine residual at the limits of the main either within acceptable limits and below the EPA's recommended minimum value or to the no chlorine scenario. In some cases, the analysis suggested there would be no chlorine within the system. This finding is supported by Risala \& Kifah (2011) [32], Ekeng \& Agunwamba (2011) [33] and Egbe \& Bassey (2016) [18] for the 125 $\mathrm{mm}$ diameter mains (Figure 7) and for the $180 \mathrm{~mm}$ diameter mains (Figure 8).

\subsection{Water Temperature}

This study assessed how fluctuations in water temperature affected the chlorine decay rate and the total amount of chlorine decay in the mains. From the literature review, it was noted that the temperature of potable water in distribution networks in Ireland can fluctuate seasonally between $5^{\circ} \mathrm{C}$ and $15^{\circ} \mathrm{C}$ (Sargeant, 2015) [34]. Therefore, to reflect water distribution conditions in Ireland, water temperatures of $5^{\circ} \mathrm{C}$ and $15^{\circ} \mathrm{C}$ were assessed for both diameters. The results are provided in Table 5 and Table 6 respectively.

Experimental studies conducted by researchers have shown that the bulk

Table 5. Chlorine decay rate for water temperatures of $5^{\circ} \mathrm{C}$ and $15^{\circ} \mathrm{C}$ in a $125 \mathrm{~mm}$ diameter trunk main.

\begin{tabular}{ccc}
\hline & \multicolumn{2}{c}{ Temperature } \\
\cline { 2 - 3 } & $5^{\circ} \mathrm{C}(278.15$ kelvin $)$ & $15^{\circ} \mathrm{C}(288.15$ kelvin $)$ \\
\hline First-order bulk decay coefficient $\left(k_{b}\right)(\mathrm{mg} / \mathrm{hr})$ & 0.03 & 0.06 \\
Zero-order wall decay coefficient $\left(k_{w}\right)(\mathrm{mg} / \mathrm{hr})$ & 0.05 & 0.05 \\
Total chlorine decay rate & 0.04 & 0.06 \\
\hline
\end{tabular}


Table 6. Chlorine decay rate for water temperatures $5^{\circ} \mathrm{C}$ and $15^{\circ} \mathrm{C}$ in a $180 \mathrm{~mm}$ diameter trunk main.

\begin{tabular}{ccc}
\hline & \multicolumn{2}{c}{ Temperature } \\
\cline { 2 - 3 } & $5^{\circ} \mathrm{C}(278.15$ kelvin $)$ & $15^{\circ} \mathrm{C}(288.15$ kelvin $)$ \\
\hline First-order bulk decay coefficient $\left(k_{b}\right)(\mathrm{mg} / \mathrm{hr})$ & 0.03 & 0.06 \\
Zero-order wall decay coefficient $\left(k_{w}\right)(\mathrm{mg} / \mathrm{hr})$ & 0.05 & 0.05 \\
Total chlorine decay rate & 0.04 & 0.06 \\
\hline
\end{tabular}

decay coefficient to be dependent on the initial chlorine residual dosage, water temperature and TOC level in the water (Feban \& Taras, 1951 [21]; Jadas-Hecart et al. 1992 [22]; Zhang et al. 1992 [23]; Powell et al. 1999 [24]; Al-Omari et al. 2004 [20]; Nagatani et al. 2006) [19]. Thus, the bulk decay coefficient equation, Equation 2 proposed by Al-Omari et al. (2004) [20], which utilises all these parameters, was used within this study. Water $\mathrm{pH}$ had a negligible effect on the bulk chlorine decay coefficient (Al-Omari et al., 2004) [20] so was not considered.

Within the analysis, the initial chlorine residual and TOC level in the water remained constant, at $1.0 \mathrm{mg} / \mathrm{l}$ and $1.8 \mathrm{mg} / \mathrm{l}$ respectively. Therefore, the water temperature was the only variable which affected the bulk decay coefficient. Studies conducted by previous researchers have shown the bulk decay coefficient to increase, as the temperature increased (Feban \& Taras, 1951 [21]; Jadas-Hecart et al. 1992 [22]; Zhan et al. 1992 [23]; Powell et al. 1999 [24]; Al-Omari et al. 2004 [20]; Nagatani et al. 2006 [19]). This finding concurs with standard chemical analysis.

The results from this study are comparable to those obtained in previous research, as indicated in Table 5 for the $125 \mathrm{~mm}$ diameter mains and Table 6 for the $180 \mathrm{~mm}$ diameter mains. Increasing the water temperature from $5^{\circ} \mathrm{C}$ to $15^{\circ} \mathrm{C}$ increased the total chlorine decay rate from $0.04 \mathrm{mg} / \mathrm{hr}$ to $0.06 \mathrm{mg} / \mathrm{hr}$ ( 1.5 fold). The results obtained in terms of the effects of water temperature on the chlorine decay rate are slightly less than those obtained by Powell et al. (2000) [24]. Powell, et al. (2000) [24] research suggested that the chlorine decay rate in the trunk mains as part of the distribution network to increase by 1.8-3.2-fold, as the temperature increased from $5^{\circ} \mathrm{C}$ to $15^{\circ} \mathrm{C}$. This may be due to other variables such as higher TOC levels in the water which were not assessed within the scope of this study. As previously stated, increasing the main diameter did not affect the chlorine decay rate within this analysis. Therefore, for this study, the parameter that influenced the chlorine decay rate and ultimately the total amount of chlorine decay in the periphery of the main was the temperature.

The findings of this study proved it was possible to calculate the chlorine decay rate, depending on the seasonal temperature, with the use of a suitable mathematical model. The results showed a positive linear relationship between chlorine decay rate and the temperature. Therefore, it may be possible to reduce the initial free chlorine residual levels at the WTP during the winter, due to a 
reduced chlorine decay rate, and increase the initial free chlorine levels at the WTP during the summer, due to an increased chlorine decay rate. It may also be possible to reduce or increase the amount of chlorine added through a chlorine booster for a given trunk main, based on the temperature or turn the chlorine boosters off or on when required. This may save money on the disinfection process. However, increasing or decreasing the initial free chlorine level is dependent on other variables such as the retention time of potable water of the main, its length and material type.

\subsection{The Costs Associated with Trunk Main Chlorine Disinfection \& Boosters}

The costs associated with trunk main chlorine disinfection and the need for boosters at the WTP and residual maintenance were calculated as part of this study for the 60 theoretical main configurations. Based on the research conducted, the chlorination costs associated with trunk main installation were impacted by the trunk main length, diameter of trunk main and the need for chlorine boosters. Increasing the length of the main in increments of $2000 \mathrm{~m}$, from 2 $\mathrm{km}$ to $10 \mathrm{~km}$ and increasing the diameter of the trunk main from $125 \mathrm{~mm}$ to 180 $\mathrm{mm}$ was expected to increase the installation costs. However, based on the comparisons conducted, it was the addition of a chlorine booster which increased and varied the costs associated with the chlorination process. An increased chlorine decay rate resulted in a reduced free chlorine residual at a shorter distance. Where the chlorine residual dropped to the EPA's (2011) [13] minimum residual value, a chlorine booster was installed which added an additional $£ 56,948.91$ to the installation costs per unit. Due to high chlorine decay rates, mains 35 and 38 required two chlorine boosters, trunk main 39 required three chlorine boosters and trunk main 40 required four chlorine boosters. Thus, the disinfection costs associated with these mains increased greatly due to the addition of multiple chlorine boosters. Furthermore, the costs associated with chlorine disinfection at the WTP and the total chlorine disinfection costs were calculated. Total chlorine disinfection costs take into consideration the costs of disinfection at the WTP and the cost of chlorine disinfection at the chlorine booster, if required.

The costs associated with chlorine disinfection at the WTP are dependent on the volume of water being distributed. Increasing the diameter of the trunk main from $125 \mathrm{~mm}$ to $180 \mathrm{~mm}$ increased the chlorine disinfection costs because the volume of potable water is distributed more than doubled (Table 3). Thus, this study has proven increasing the diameter of a trunk main to have an influence on the costs associated with chlorine disinfection.

The total chlorine disinfection costs depend on the need for a chlorine booster, chlorine decay rate and the volume of potable water in the main. Based on the comparisons completed, the need for additional chlorine and a chlorine booster greatly increased the total chlorine disinfection costs per day, particularly the trunk main which required multiple booster systems. The key parame- 
ters influencing the total amount of chlorine decay in the periphery of the main was the length and diameter. Therefore, this study has shown through its multiple comparisons that although the length of a trunk main cannot be reduced, operational expenditure could possibly be saved (on gravity mains) by maintaining a free chlorine residual in the network by implementing the trials currently being conducted to reduce the diameter of trunk mains (Rosario-Ortiz \& Speight, 2016) [35]; however, further research is needed in this area.

Based on the results obtained, this analysis has shown the importance of environmental conditions in relation to the costs associated with trunk main chlorine disinfection at the WTP and the total chlorine disinfection in the main to maintain a residual within acceptable limits. Therefore, during the design process, it is important to take environmental factors, such as seasonal temperature and water TOC levels into consideration, as these parameters have been shown to influence the costs significantly.

\subsection{Limitations to This Study}

There are several limitations to this study as follows:

1) The study looked at a limited amount of pipe diameters, looking at small diameter trunk mains only with maximum distances of $10 \mathrm{~km}$.

2) A population was used to calculate the draw-off rates over a 16-hour period per 24 hours. This domestic population did not take business or agriculture into account.

3) The pipework was judged to be new with no build-up on the inside of the pipe wall. A build-up on the pipe wall internally could allow chlorine to be absorbed thus altering results considerably.

4) The entire distribution network was not considered as part of this study, reservoirs, distribution mains and house connections all affect chlorine decay.

5 ) The purchase cost of chlorine was based on a commercial rate supplied to a civil engineering contractor who specialises in laying water mains, including disinfection processes. A water company would be able to obtain a lower rate for purchasing chlorine in bulk. While a reduced chlorine cost would reduce the financial information reported in this study. However, this does not change the outputs from the remaining analysis.

6) Hydraulic considerations in terms of head losses in smaller diameter trunk mains were not considered. Smaller diameter mains could have considerable cost implications in terms of pumped systems.

7) TOC levels in the water were not assessed beyond $1.8 \mathrm{mg} / \mathrm{l}$.

8) A detailed statistical analysis was not completed which ranks the significance of each variable that was established.

\section{Conclusions and Recommendations for Further Work}

The following are the observations from this study in terms of variables such as trunk main length, dimeter, temperature along with water demand (population) 
and the impact of these variables on chlorine decay.

\subsection{Population}

This study identified the number of consumers drawing water from a trunk main to impact the quality and quantity of the free chlorine residual at the outer limits of any water distribution system. The study identified how low consumer draw-off rates, increased main length and diameter size to increase the risk of the free chlorine residual not complying with the EPA's (2011) [13] recommended minimum residual value.

\subsection{Trunk Main Length}

The effects of main length on the total amount of chlorine decay and the availability of a free chlorine residual at the periphery of the main were assessed in this study. The analysis showed that increasing the length of the trunk main in increments of $2000 \mathrm{~m}$, from $2 \mathrm{~km}$ to $10 \mathrm{~km}$, was the major cause of chlorine consumption and decrease in residual chlorine concentrations. If the free chlorine residual dropped to the EPA's minimum residual value of $0.1 \mathrm{mg} / \mathrm{l}$, a chlorine booster was implemented (EPA, 2011) [13]. A total of 16 of the 20 trunk mains assessed with 200 consumers required a chlorine booster. Furthermore, 6 of the 20 trunk mains assessed with 500 consumers required a chlorine booster and 1 of the 20 trunk mains assessed with 1000 consumers required a booster. This will have significant direct and indirect financial and maintenance costs for the managers of these assets.

\subsection{Trunk Main Diameter}

Two SDR11 MDPE trunk mains of $125 \mathrm{~mm}$ and $180 \mathrm{~mm}$ diameter were analysed to assess how changing the diameter of the trunk main would impact the chlorine decay rate and the total amount of chlorine decay. Based on the calculations undertaken, increasing the diameter of the trunk main from $125 \mathrm{~mm}$ to $180 \mathrm{~mm}$ had a negligible effect on the results obtained. The results were contradictory to those obtained from experimental studies by Risala et al. (2011) [32], Ekeng et al. (2011) [33] and Egbe \& Bassey (2016) [18]. Their work suggested that the rate of chlorine decay to increase in smaller diameter mains and decrease in larger diameter mains. In this study, the chlorine decay rate did not fluctuate when the trunk main diameter increased from $125 \mathrm{~mm}$ to $180 \mathrm{~mm}$, the possible reason for this is outlined in part 4.6 (3).

\subsection{Temperature}

This study assessed how fluctuations in water temperature affected the chlorine decay rate and the total amount of chlorine decay in the mains. The results of this analysis have shown that increasing the water temperature from $5^{\circ} \mathrm{C}$ to $15^{\circ} \mathrm{C}$ increased the chlorine decay rate by 1.5 -fold, from $0.04 \mathrm{mg} / \mathrm{hr}$ to $0.06 \mathrm{mg} / \mathrm{hr}$. As previously stated, increasing the main diameter did not affect the chlorine decay 
rate. Therefore, the parameter that most influenced the chlorine decay rate and ultimately the total amount of chlorine decay in the main was the water temperature.

\subsection{Costs Associated with Chlorine Disinfection}

The costs associated with trunk main chlorine disinfection at the WTP and total chlorine disinfection were calculated for the 60 hypothetical trunk mains, the remainder of the distribution network was not specifically considered as part of this study apart from draw off rates. However, the costs must be balanced against the need for a potable water that is microbially safe to consume by everyone who draws water from the main. Based on the research conducted, the chlorination costs are affected by the trunk main length, diameter of trunk main and the need for a chlorine booster. However, based on the comparisons conducted, it was the addition of a chlorine booster which greatly increased and varied the costs associated with trunk main. The analysis suggests that consumer draw-off rates, trunk main length, diameter of trunk main and water temperature dictated the need for a chlorine booster. Consumer draw-off rates and trunk main length and diameter affected the retention time of potable water in the main and the water temperature affected the chlorine decay rate. This study found low consumer draw-off rates, increased main lengths, increased diameters and increased water temperatures resulted in an increase in the total amount of chlorine decay in the main. Thus, more chlorine boosters were required to ensure the residual remained above the EPA's (2011) [13] recommended minimum value of $0.1 \mathrm{mg} / \mathrm{l}$.

Based on the comparisons conducted in this study, increasing the diameter of the trunk main from $125 \mathrm{~mm}$ to $180 \mathrm{~mm}$ increased the chlorine disinfection costs because the volume of potable water is carried more than doubled (Table 3).

The key parameters that influenced the total amount of chlorine decay in the periphery of the main were the length and diameter of the main. Therefore, this study has shown through its multiple comparisons that, where the length of a trunk main cannot be reduced, money can be saved on maintaining a free chlorine residual in the network by implementing the trials currently being conducted to reduce the diameter of trunk main diameters (Rosario-Ortiz \& Speight, 2016) [34].

\subsection{Recommendations for Further Research}

The following list provides recommendations for further research based on the knowledge gaps that were identified through this study:

- This study found that increasing or decreasing the trunk main diameter had a negligible effect on the chlorine decay rate due to the use of MDPE pipe material. This is contradictory to research conducted by Risala \& Kifah (2011) [32], Ekeng \& Agunwamba (2011) [33] and Egbe \& Bassey (2016) [18]. It is 
recommended that further research is conducted to evaluate how trunk main diameter and pipe material affect the chlorine decay rate. See 4.6, limitations to this study.

- A wider variety of trunk main diameters should be assessed; furthermore, different pipe materials should be used to assess how these factors influence the chlorine decay rate, based on the same simulated conditions.

- To further assess the bulk decay coefficient and the total amount of chlorine decay in the periphery of the main, more temperatures are required to be assessed between $5^{\circ} \mathrm{C}$ and $15^{\circ} \mathrm{C}$. This will enable the chlorine decay rate to be calculated at temperatures between the minimum and maximum water temperatures recorded in distribution networks in Ireland, as reported by Sargeant (2015) [35].

- The initial free chlorine residual and/or the water TOC levels could be set as variables to assess how changing these parameters would affect the bulk decay coefficient, chlorine decay rate and ultimately the total amount of chlorine decay in the periphery of the overall distribution network.

- Greater use of alterative disinfection processes at the WTP, such as ozone, UV light or "The Dutch Secret" [36] in terms of "how to provide safe drinking water without chlorine" should be assessed for Irish water conditions. The results obtained from further research could then be compared to the results obtained from this study. Comparisons could be made between the quality of potable water produced at the WTP and the quality of potable water obtained by consumers. Additionally, the costs associated with disinfection and installation of disinfection contactor systems and trunk mains could be compared.

- A chloramine residual in the distribution network could be assessed as part of further research on the topic. A comparison could be made between the results obtained in the research project, using a free chlorine residual, to those obtained with a chloramine residual, based on Irish water conditions.

- Complete water networks should be analysed to include the entire distribution system from water treatment plant, storage reservoirs, trunk mains, local distribution mains and house connections.

- The impact of using smaller diameter watermains when considering chlorine decay on the hydraulic performance of watermains should be explored further in terms of value engineering.

\section{Conflicts of Interest}

The authors declare no conflicts of interest regarding the publication of this paper.

\section{References}

[1] LeChevallier, M. and Au, K. (2004) Water Treatment and Pathogen Control: Process Efficiency in Achieving Safe Drinking Water. IWA Publishing, London. 
[2] Abdullah, M., Yew, C. and bin Ramli, M. (2003) Formation Modeling and Validation of Trihalomethanes (THM) in Malaysian Drinking Water; a Case Study in the Districts of Tampin, Negeri Sembilan and Sabah Bernam, Selangor, Malaysia. Water Research, 37, 4637-4644. https://doi.org/10.1016/j.watres.2003.07.005

[3] Boccelli, M., Tryby, J., Uber, R. and Summers, R. (2003) A Reactive Species Model for Chlorine Decay and THM Formation under Rechlorination Conditions. Water Research, 37, 2654-2666. https://doi.org/10.1016/S0043-1354(03)00067-8

[4] Sohn, J., et al. (2004) Disinfectant Decay and Disinfection By-Products Formation Model Development: Chlorination and Ozonation By-Products. Water Research, 38, 2461-2478. https://doi.org/10.1016/S0043-1354(04)00132-0

[5] Purcell, P.J. (2003) Design of Water Resources Systems. Thomas Telford, London. https://doi.org/10.1680/dowrs.30985

[6] European Union (EU) Drinking Water Directive 98/83/EC of 3rd November 1998.

[7] EPA and HSE (2011) Joint Position Statement-Trihalomethanes in Drinking Water. HSE, Dublin.

[8] Hass, C. and Kara, S. (1984) Kinetics of Wastewater Chlorine Demand Exertion. Journal of the Water Pollution Control Federation, 56, 170-173.

[9] EurEau (2014). http://www.eureau.org

[10] Silva, G.D.L., Bruning, H. and Rulkens, W. (2010) Anaerobic Effluent Disinfection Using Ozone: By-Products Formation. Bioresource Technology, 101, 6981-6986. https://doi.org/10.1016/j.biortech.2010.04.022

[11] Kohpaei, A. and Sathasivan, A. (2011) Chlorine Decay Prediction in Bulk Water Using the Parallel Second Order Model: An Analutical Solution Development. Chemical Engineering Journal, 171, 232-241. https://doi.org/10.1016/j.cej.2011.03.034

[12] Spellman, F. (2004) Mathematics Manual for Water and Wastewater Treatment Plant Operators. CRC Press, Boca Raton. https://doi.org/10.1201/9780203502662

[13] EPA (2011) Water Treatment Manual: Disinfection. Environmental Protection Agency, Wexford.

[14] WHO (1996) Chlorine in Drinking-Water. In: Guideline for Drinking Water Quality, WHO, Geneva, 2nd Edition, Vol. 2, 1-6.

[15] DWI (2010) Chlorine. Drinking Water Inspectorate, London.

[16] Lu, W., Kiene, L. and Levi, Y. (1999) Chlorine Demand of Biofilm in Water Distribution Systems. Water Research, 33, 827-835. https://doi.org/10.1016/S0043-1354(98)00229-2

[17] Speight, V. (2008) Water-Distribution Systems: The Next Frontier. In: Bugliarella, G., Ed., The Bridge: Linking Engineering and Society, National Academy of Engineering, Washington DC, 31-37.

[18] Egbe, J. and Bassey, G. (2016) Residual Chlorine Decay in Water Distribution Network. International Journal of Scientific Research and Engineering Studies, 3, 1-6.

[19] Nagatani, T., et al. (2006) Residual Chlorine Decay Simulation in Water Distribution System. 7 th International Symposium on Water Supply Technology, Yokohama, 22-24 November 2008, 1-11.

[20] Al-Omari, A., Fayyad, M. and Al-Nimer, A. (2004) Modelling Chlorine Residuals at Jabal Amman Water. Journal of Water Supply. Research and Technology, 53, 351-358. https://doi.org/10.2166/aqua.2004.0028

[21] Feban, D. and Taras, M. (1951) Studies on Chlorine Demand Constants. Journal 
American Water Works Association, 43, 922-932.

https://doi.org/10.1002/j.1551-8833.1951.tb19057.x

[22] Jadas-Hecart, A., et al. (1992) Modeling the Chlorine Demand of Treated Water. Water Research, 26, 1073. https://doi.org/10.1016/0043-1354(92)90143-R

[23] Zhang, G., et al. (1992) Modelling of Chlorine Residual in the Water Distribution Network of Macao. Environmental Technology, 13, 937-946. https://doi.org/10.1080/09593339209385229

[24] Powell, J., et al. (1999) Factors Which Control Bulk Chlorine Decay Rates.. Water Research, 34, 117-126. https://doi.org/10.1016/S0043-1354(99)00097-4

[25] Hallam, N., et al. (2002) The Decay of Chlorine Associated with the Pipe Wall in Water Disinfection Systems. Water Research, 36, 3479-3488. https://doi.org/10.1016/S0043-1354(02)00056-8

[26] Cem-Kaner, J. (2013) An Introduction to Scenario Testing. Florida Institute of Technology, Melbourne, 1-13.

[27] Casey, T., Kearney, P. and Kerr, H. (2012) The Chlorine Demand Characteristics of Irish Water Supplies. CIWEN, Dublin.

[28] NISRA (2011) Census 2011 Population Tables. Northern Ireland Statistics and Research Agency, Belfast.

[29] Ó'Fátharta, C. (2013) 150 Litres of Water Consumed Daily by Every Person. Irish Examiner, 11 October.

[30] EPA (1999) Alternative Disinfectants and Oxidants Guidance Manual. EPA, Washington DC.

[31] Shamsaei, H., Jaafer, O. and Basri, N. (2013) Effects Residence Time to Water Quality in Large Water Distribution Systems. Scientific Research Engineering, 5, 449-457. https://doi.org/10.4236/eng.2013.54054

[32] Mohammed, R.A. and Khudiar, K.M. (2012) Effects of Flow Rate and Pipe Diameter on Wall Chlorine Decay Rates. Al Taqani, 25, E-134.

[33] Ekeng, E. and Agunwamba, J. (2011) The Effect of Pipe Ageing of Different Diameter and Pressure on Residual Chlorine. LAP Lambert Academic Publishing, Saarbrücken.

[34] Rosario-Ortiz, F. and Speight, V. (2016) Can Drinking Water Be Delivered without Disinfectants like Chlorine and Still Be Safe.

https://theconversation.com/can-drinking-water-be-delivered-without-disinfectants -like-chlorine-and-still-be-safe-55476

[35] Sargeant, M. (2015) What Is the Temperature Range of My Water Supply. https://www.quora.com/Gas-Boilers-What-is-the-temperature-range-of-my-cold-w ater-supply

[36] Smeets, P.W., Medema, G.J. and Van Dijk, J.C. (2009) The Dutch Secret: How to Provide Safe Drinking Water without Chlorine in the Netherlands. Drinking Water Engineering and Science, 2, 1-14. https://doi.org/10.5194/dwes-2-1-2009 